\title{
94 Tスパン天井の設計・積算システム
}

\section{( TAC システム)}

西崎清。大八木幸三橋本敏郎岩田信男芝垣秀樹

1 まえがき

Tスパンシステし天井の設計 - 積算業務は多大な労力と時間を要していたか、大型計

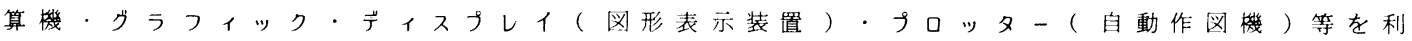
用し、設計・積算の大部分を占める機械的作業をそれらにあかせ、設計者はアイゴアの提 供、処理途中結果の判断、修正指示等を図形を媒体とした会話方式で、試行錯誤しながら 行ない、短時間で設計者のアイデアを生かした図面・積算リスト作成が出来るシステし（ T A C システし) を開発したのて、その概要を報告する。

\section{2 システム概要}

下図に示すよ5に、グラフィック・゙゙ィスアレイを大型計算機とオンラインで結び、イ ンテリジェント・グラフィック・ターミナルとして使用し、アロッターはオフラインで図

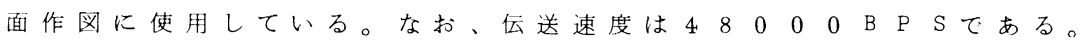

クラフィック・ティスプレィ

大型計 筆 機

プッター

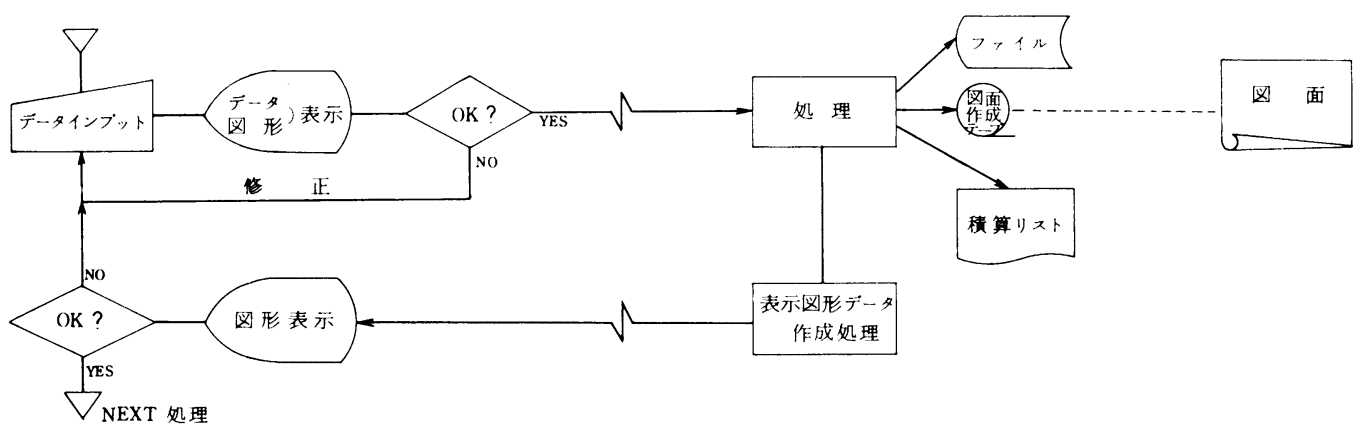

\section{3 処理手順と機能}

(1) グラフィック・ディスアレイと対話しながら、各種情報をインクットし、画面上に 表示された数值や図形を目でチェックし、修正の必要あれは、その筒所をライトペン でヒットし修正する。全てが正しくインクットされれば、大型計算機へデータを伝送 する。

(2)大型計算機では各種の必要な処理を行ない、その結果をデスクに七イグし、かつ グラフィック・ディスアレイの画面上に表示出来る図形データを作成して、クラフィ ツク・゙ィスアレイベ゙ータを伝送する。

(3) グラフィック・ディスフレイの画上で図形をチェックし、修正の必要あれば、(1) に戾り、正しければ次の処理へ移る。

(4)処理の種類には、建築図面情報処理・器具配置処理・伏図の修正処理・設備機器の 配、置処理・積算処理等がある。

(5) 全ての処理が終了すると、天井伏図、インサート・スペーサ配直図用のテーアを作 成し、アロッターで図面を作成する。かつ、積算りストをフリントする。

4 あとがき

このミステし開発にあたつて、絶大な協力を睗つた日本コこバックの生沢氏に感謝の意を表します。 